\title{
EU-Russian Relations and Turkey's Role as an Energy Corridor
}

\section{Ali Tekin \& Paul A. Williams}

To cite this article: Ali Tekin \& Paul A. Williams (2009) EU-Russian Relations and Turkey's Role as an Energy Corridor, Europe-Asia Studies, 61:2, 337-356, DOI: 10.1080/09668130802630896

To link to this article: https://doi.org/10.1080/09668130802630896

曲 Published online: 19 Feb 2009.

Submit your article to this journal ๘

Џll Article views: 704

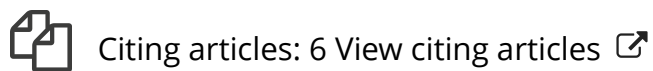




\title{
Discussion Article
}

\section{EU-Russian Relations and Turkey's Role as an Energy Corridor}

\author{
ALI TEKIN \& PAUL A. WILLIAMS
}

\begin{abstract}
This article analyses the impact of EU-Russian relations on Turkey's role as a corridor for the transit of energy supplies to Europe. While the European Union (EU) has inherent leverage in its collective purchase of most Russian gas exports, market power has shifted in Russia's favour. Russian efforts to build new pipelines and widen downstream access have stimulated EU interest in diversifying energy imports and transit routes. In this sense, the EU has recognised Turkey's potential value as a secure and independent route for importing non-Russian energy supplies, which may in turn have an impact on Turkey's EU accession process.
\end{abstract}

POLICY MAKERS IN EUROPEAN UNION (EU) countries and institutions have grown increasingly concerned with energy security. The cut-off of gas supplies to Ukraine by Gazprom, the Russian state-run monopoly, on 31 December 2005 was an 'eye-opener' for the EU. According to Benita Ferrero-Waldner, the EU's external relations commissioner, it had the effect of raising the status of energy to the forefront of the Union's foreign policy agenda (Rettman 2006). The Commission's March 2006 Green Paper stressed the necessity of transparency and predictability for promoting 'security of supply by sending the right investment signals to participants', and also underscored that 'security against political risks including interruption of supply is critical to predictability' (European Commission 2006a, p. 8). A major oil cut-off by Russia's monopoly Transneft pipeline operator to a transit country, Belarus, in January 2007, prompted further concern and provided part of the backdrop to the issuance of a proposed Energy Policy for Europe (European Commission 2007a).

While the EU's conception of the objective of 'energy security' includes demand management and environmental goals, secure access to physical supplies also constitutes a core motif. The EU has thus far been incapable of embarking on the path of militaristic energy security as pursued by the US government in Iraq (Williams 2006); yet, powerful imperatives suggest greater 'securitisation' of EU energy policy goals, in the sense of making them so 'urgent and existential' that they 'should not be 
exposed to the normal haggling of politics but should be dealt with decisively by top leaders prior to other issues' (Buzan et al. 1998, p. 29).

Some of these key imperatives stem from the nature and dynamics of EU-Russian energy relations. From one angle, Russia appears just as dependent on European markets to earn necessary foreign currency reserves as Europe is reliant on Russian gas, especially since leading Russian energy firms lose money in heavily subsidised domestic retail markets. By the same token, foreign investment, which may be crucial to upgrading the productivity of declining fields and mitigating likely output shortfalls, cannot be cheaply excluded from Russia's upstream sector. Thus, the externally dependent profile of the Russian Federation's domestic economy and energy sector may seem intrinsically compatible with EU energy security.

Yet, energy market power has broadly shifted in recent years in favour of producing states. Accordingly, the latter have engaged in unilateral moves to alter the terms of foreign direct investment (FDI) in their respective upstream sectors, typically in a more restrictive direction, and, in some cases, individually and collectively, they have embarked on developing the related physical and institutional capacity to divert exports among customers and to coordinate export activity. The Russian government has avoided overt asset confiscation (a signature form of 'resource nationalism'), preferring to condition upstream-sector openness on the reciprocal willingness of the EU to grant access to its member states' downstream sectors and to support Russianled transit projects bypassing contentious routes through Belarus and Ukraine. However, in the larger context of growing inter-producer alliances, featuring upstream joint ventures, monopsonistic purchasing arrangements [notably from Central Asian former Soviet Union (FSU) states] and potential market coordination of liquefied natural gas (LNG) supplies, Russian efforts to obtain downstream access and control pipeline exports have stimulated EU interest in diversifying energy imports and transit routes.

It is in this context of EU-Russian energy relations that the EU as a body has recognised Turkey's potential value as a relatively secure and independent route for importing non-Russian energy supplies (Tekin \& Walterova 2007). In particular, the EU has signed an intergovernmental accord supporting the Nabucco gas pipeline, which could transform Turkey into a major conduit for up to 35 billion cubic meters (bcm) of various non-Russian gas supplies to Europe. Energy Commissioner Andris Piebalgs, who signed the accord on behalf of the EU, endorsed this project as 'essential to Europe and the EU's most important gas supply project' (Socor 2006d). This raises the question of whether or not energy security requirements, one of the most salient aspects of EU relations with Russia, will come to influence considerations of Turkey's full accession into the Union. While this cannot be definitively ascertained, energyrelated factors may work in favour of such an outcome.

The first section of this article briefly surveys how EU energy security has increasingly come to rely on imports. The following section focuses on the evolution of energy-centric economic interdependence between the EU and Russia, highlighting how the seller's market in energy has increased the saliency of Europe's dependence on Russia and the EU's identified need to diversify supply sources as well as transit routes. The third section analyses the potential role of Turkey as a conduit, independent of Russia, for third-party gas supplies to Europe, notably from former 
Soviet Central Asian countries, and the extent to which that role might have implications for Turkey's EU accession bid. The fourth section considers how energy factors into Turkey's EU accession bid.

\section{European Union energy security}

The EU's chances of obtaining energy security through self-sufficiency are admittedly low. European Economic Area (EEA) oil reserves are declining due to the maturity of fields in the North Sea, although this is still a major indigenous source of gas. Four fifths of Europe's fossil fuel reserves comprise solid fuel, yet, ironically for an organisation that originated in the 1952 European Coal and Steel Community (ECSC), extraction of coal in the EU now costs between three and four times the world average. This has led major EU-15 economies to decrease mining activity (European Commission 2001, pp. 19-20). Moreover, the European Commission recognises that maintaining the one-third share of Europe's electricity output that is generated by coal and lignite, which are major contributors to $\mathrm{CO}_{2}$ emissions, requires the implementation of 'commercialised carbon sequestration and clean coal technologies' (European Commission 2006a, p. 9). More than one third of the Union's electricity and $15 \%$ of its overall energy are supplied by nuclear power, yet, even in a seller's market for hydrocarbon fuels, expanding the use of this energy source has yet to overcome the opposing concerns of many EU citizens about waste disposal and safety (European Commission 2007a, pp. 17-18). The average use of renewable resources averages $6 \%$ across EU member states, a rate that may double by 2010 and treble by 2020 . While the latter target encompasses a $10 \%$ biofuel mix in all petroleum and biodiesel fuels, even this seemingly reasonable goal is unlikely to be reached (European Commission 2007a, pp. 13-15).

Thus, the EU's need for external fuel sources is set to rise. Between 1997 and 2007, EU-area self-sufficiency in oil consumption declined from $24 \%$ to $16 \%$, while that fraction of natural gas consumption available from area sources fell from $56 \%$ to $40 \% .^{1}$ The 27 member states now import over half their collective natural gas and oil requirements and will probably rely on imports to meet over $80 \%$ and $90 \%$ of their collective natural gas and oil needs, respectively, in the next two decades (European Commission 2007a, p. 3). Although emphasising the importance of attaining greater efficiency in energy usage, the European Commission (2001, pp. 29-30) acknowledges the practical difficulty of decreasing EU reliance on imports. Therefore, the EU faces an increasingly urgent need to develop new policies in order to ensure the most propitious terms of access to diverse energy sources and suppliers.

\section{EU-Russian energy relations}

Pronounced EU reliance on oil and gas imports is exacerbated by the nature and limited number of its source regions. As Russia supplies one-quarter of EU gas consumption and $40 \%$ of its total import requirements (derived from British Petroleum 2008), while Middle Eastern OPEC states account for a slightly larger

\footnotetext{
${ }^{1}$ Figure derived from British Petroleum (2008).
} 
fraction of the EU's imported oil, it makes political-economic sense for the EU to diversify its supply sources (European Commission 2001, p. 2). Nonetheless, despite advocating greater diversification of energy sources and suppliers, the European Commission (2001, pp. 22-23) understands that the present profile of EU hydrocarbon dependence on Russia, the Caspian, the Middle East and North Africa is unlikely to change markedly. While gas imports from Norway occur within the scope of the EU gas directive, those from Russia (and Algeria) fall outside the EU's regulatory compass. As the EU energy market liberalises under European Commission pressure on national authorities to 'unbundle' the ownership of energy production from control of distribution, Russia's Gazprom has been endeavouring not only to expand trunk-pipeline capacity, but also to acquire influential shares, via intermediary marketing companies, in local storage nodes and distribution channels within the European Union, as it has been attempting to accomplish in numerous FSU countries (Socor 2006a; Woehrel 2007, pp. 7-13). These efforts aim to capture monopoly rents created by large differentials between low production costs and high retail prices (Victor \& Victor 2006, pp. 138-39).

\section{EU energy security via mutual economic interdependence with Russia}

In and of itself, Gazprom's plan to expand its presence in Europe's downstream sector does not necessarily signal the impetus of any motive other than profit and securing its extant customer base. While two fifths of the EU's respective gas and oil import baskets are supplied by Russia, the EU actually relies more, in terms of overall consumption, on imports of Russian oil than on those of gas (derived from British Petroleum 2008). In economic terms, though its 2007 trade in mineral fuels with the Russian Federation accounted for over half of the EU-27's overall trade deficit, these imports made up less than $7 \%$ of the total value of EU imports and an infinitesimal fraction of the EU's overall 2007 GDP of nearly $€ 13$ trillion. ${ }^{2}$ Conversely, although Russia consumes nearly one quarter of its oil output and three quarters of its natural gas production, it exports nearly all of its remaining oil and gas supplies to the EU area. Moreover, compared to the minor place of hydrocarbon imports in Europe's trade balance and overall economy, oil and gas together comprised nearly half Russia's total 2006 exports by value and roughly $15 \%$ of its overall GDP (World Bank 2007). This would imply that Russia cannot facilely embargo energy supplies to European customers, as it has done with FSU importing countries, without harming its own economic interests.

Moreover, because the domestic retail market is heavily subsidised (more so for residential than industrial customers), state energy firms, notably Gazprom, require revenue from European and other foreign entities, either as customers or joint investors, to maintain and upgrade the basic production capacity of Russia's fields (Roberts 2006, pp. 220-21; Victor \& Victor 2006, pp. 139-41). As an institutional actor, the EU thus has some leverage to insist, in its various 'dialogues' with the Kremlin, on a broad array of liberal reforms in the Russian (energy) economy. These

${ }^{2}$ Compiled from Eurostat, available at: http://epp.eurostat.ec.europa.eu/portal, accessed 31 July 2008. 
include continued openness (or no further closure) of the upstream sector to foreign corporate investors; ratification of the Energy Charter Treaty (ECT) and its ancillary Transit Protocol, the latter requiring non-discriminatory and unfettered access to trans-Russia pipelines, especially those originating in other FSU states; and rationalisation of domestic energy tariffs in line with market prices (Socor 2008d).

\section{Alternative energy transit corridors to Europe for Russia}

However, as it remains dependent on a limited range of sources and suppliers, the EU area at minimum bears the risk of supply cut-offs occurring as by-products of disputes between producer and transit countries. This became starkly apparent when Gazprom shut off gas supplies on 31 December 2005 to Ukraine, which in turn diverted gas deliveries in the TransGas pipeline from European to domestic customers (Chivers 2006). ${ }^{3}$ During the subsequent winter, Transneft, the state-run monopoly operator of oil pipelines crossing Russian territory, stopped the flow of Russian oil exports to Europe via a transit country, Belarus, due to an energy-related trade dispute involving a similar act of oil siphoning by the latter's government (Myers 2007). In early March 2008, the recurring Russo-Ukrainian dispute over Ukraine's unpaid gas bills led to Gazprom's halving of deliveries to Ukraine, where officials openly threatened to cut shipments to EU customers (White 2008). Although these disputes have roots in the USSR's collapse, which left an integrated infrastructure divided among competing states (Larsson 2007), they have been aggravated by high energy prices, which raised suppliers' costs of maintaining subsidies to FSU countries while enabling the Kremlin to punish those among the latter that have tried to exit the Russian sphere of influence (Williams 2007). Because the key FSU importers in question also serve as transit countries, they can shift the burden of supply cut-offs onwards to successive European consumers, thus giving some EU members a common interest with Russia in finding alternate export routes.

Turkey's candidacy as a major energy corridor to Europe lies in its geographical propinquity to the energy-rich regions of Russia, the Caspian Basin and the Persian Gulf (thus complementing Europe's relatively favourable terms of access to North African sources). In fact, Turkey lies near regions possessing over $70 \%$ of the world's proven oil and gas reserves (Roberts 2004, p. 1). The United Nations Economic Commission for Europe (2006, p. 9) has estimated that Turkey may host 6-7\% of global oil transport by 2012. Nonetheless, although Turkey's role as an oil-transit country is important for regional exporters, it is less vital for global importers because of oil's greater fungibility (Roberts 2004, p. 19). By contrast, states in producing

\footnotetext{
${ }^{3}$ Alternative accounts of the Ukrainian cut-off focus not only on the upsurge in Russian demand during an unusually cold winter, which might be considered a proximate cause, but also on a number of interrelated background factors. These include heavily subsidised domestic gas prices relative to European retail prices hence, leaving customers with little incentive to conserve; Gazprom's heavy acquisition of non-core assets, part of a political strategy that has left it highly indebted; and Russia's difficulty in attracting foreign investment to develop new fields to replace declining reserve sources. Thus, it appears logical for Gazprom, despite other FSU countries' resistance, to seek higher retail prices or larger shares of distribution networks in Ukraine and its other subsidised export markets (Johnson 2005, pp. 269-71; Victor 2006; Victor \& Victor 2006, pp. 139-41).
} 
regions holding over one third of gas reserves have expressed varying degrees of interest in using Turkey as a transit country to the EU (Roberts 2004, p. 1).

Expressions of interest have emanated from Russia, the headquarters of companies, like Gazprom, that view Turkey's land mass (as opposed to its extant maritime route, the Bosphorus Straits) as an alternative to Ukraine. Now hosting the twin BakuTbilisi-Ceyhan (BTC) oil and Baku-Tbilisi-Erzurum (BTE) gas pipelines, which bring Azerbaijani offshore hydrocarbons to world markets without traversing Russia, Ankara has some capacity to resist becoming another Russian-dominated transit corridor, as reflected in its insistence on rights to re-export Turkey's unused fraction of Russian (and Iranian) gas imports to EU states as well as in its related suspensions of gas imports contracted for on a 'take-or-pay' basis (Winrow 2004, pp. 29-30). However, Turkey's ability to act independently in the transit sector appears heavily constrained by its own dependence on Russia for over three fifths of its own gas consumption (British Petroleum 2008). Accordingly, Gazprom is advantageously poised to enlist Turkey as a transit route for its own gas as part of a larger strategy to monopolise (and monopsonise) energy supplies and their export. Having pursued the creation of trading companies with opaque structures of ownership in Europe, the acquisition of transit lines and the purchase of local distribution outfits (Roberts 2006, p. 219), Gazprom has had a notably corrupting influence on EU member and candidate countries (Winrow 2003).

More specifically, the joint Russo-Italian-Turkish 'Blue Stream' project, operational since 2003 and capable of piping up to $16 \mathrm{bcm}$ of Russian gas to Turkey, could be expanded (in a second phase) to act as a Southern complement to the Northern European Gas Pipeline ('Nord Stream'). The latter Russo-German project is to link Russia's Yamal Peninsula fields via the Baltic Sea to Germany and elsewhere in Europe, circumventing Ukraine, Poland and EU-member states of the Baltic Sea region and raising related security issues for EU member states (Belkin 2007, p. 4; Larsson 2007). 'Blue Stream II' envisages converting Turkish pipelines into a Gazprom conduit to Europe via Greece, potentially co-opting the South European Gas Ring to bar independent transport of Caspian gas (Kramer 2005). Indeed, Gazprom has offered to invest in expanding the capacity of the Turkey-Greece Interconnector and guarantee Russian gas for it (Torbakov 2006b), while one EU member-state firm of the Nabucco consortium has even proposed using Blue Stream gas in that project, contradicting the very raison d'etre of Nabucco (Socor 2008b).

Russia has hedged its bets on co-opting the Turkish transit corridor by arranging for a larger array of non-Turkish routes to European markets. In terms of gas, Gazprom has backed the 'South Stream' project, which is to cross the Black Sea to Bulgaria and onwards to Greece and Italy (Eni is Gazprom's project partner) via one branch and to Serbia, Hungary and Austria via a second branch (Brunwasser \& Dempsey 2008). As for oil, Transneft has been cooperating with the Italian company Eni, as well as with Bulgaria and Greece, in undertaking to build the BurgasAlexandropolis oil export route, which is also to cross the Black Sea to reach Bulgaria (Burgas) and then Greece (Alexandropolis), thus bypassing the tanker-choked Bosphorus Straits and Turkey altogether (Shiryaevskaya 2008). Consequently, transit projects spearheaded by Russia have the potential to achieve what is called here 'near encirclement'- that is, a northerly and southerly pipeline-based route bypassing not 
only Belarus, Ukraine, and possibly Turkey, but also some of the EU's most antiRussian newcomers, the Baltic states and Poland.

\section{Ensuring EU energy security vis-à-vis Russia in a seller's market}

In contrast to the more sanguine portrayal of EU-Russian interdependence depicted above, the post-2001 emergence of an energy seller's market has tilted the balance of advantages in Russia's direction. While average crude oil prices nearly trebled between 2001 and 2007, natural gas prices, which are generally indexed to oil and segmented by market, rose over the 2002-2007 period most steeply - by a factor of nearly 2.5 - for EU customers (derived from British Petroleum 2008). This price increase, which helped Russia retire Soviet-era sovereign debt and increase its foreign reserves from $\$ 12$ billion in 1999 to $\$ 470$ billion in 2007 (United States Central Intelligence Agency 2008), signalled that Russia could earn more hydrocarbon revenues without attending as much to the need to bolster its long-term capacity to increase output. Thus, Russia has slowed or even reversed the pace of liberalisation of the Russian upstream sector that was prompted by the buyer's market of the 1990s, as manifested in unilateral government-backed efforts to increase the share of state-led firms in various joint energy projects at the expense of foreign corporate investors (Williams 2007; Kramer 2008 b). Reflecting a trend towards more frequent passage of domestic legislation that is less friendly to foreign corporate interests (Shan 2007), the post-Putin Medvedev government has legalised restricting development of Russia's offshore hydrocarbon reserves to national state-controlled entities (Rodova 2008b).

Given its interest in obtaining World Trade Organisation (WTO) membership and greater latitude for Gazprom to buy into Europe's downstream networks, the

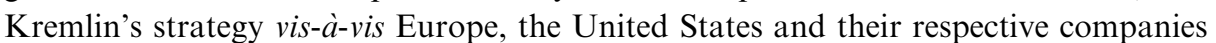
does not resemble the most overt form of 'resource nationalism'. Russia has allowed foreign corporate investors to remain in, or to enter anew into, various joint partnerships, albeit with minority shares (up to $49 \%$ ). It has offered select Western and Asian multinationals limited access to Russia's energy reserves, primarily offshore blocks located in far eastern Siberia (notably Sakhalin Island) and further west (the Shtokman gas fields), slated to give Russia a future capacity for liquefied natural gas (LNG) exports. At the same time, projects of this sort lay a physical foundation for Russia's subtle threats, directed against Europe, to ship LNG elsewhere and divert more piped energy to East Asia (Baev 2006; Romero 2006; Torbakov 2006a; Shiryaevskaya \& Kumagai 2008).

\section{Turkey's potential to compete with Russia in transporting third-party energy supplies to Europe}

Russian energy interests have used seller's market conditions to do more than defend market share. They have acted to strengthen their influence in other third-party regions, including the Caspian Sea basin (most notably), the Middle East and even Africa, where key producers are either supplying European energy consumers directly or seeking to supply the latter indirectly, via the transit through Turkey. This apparent Russian strategy of expanding further afield into newer extra-regional and global 
(LNG) energy sectors - what might be called 'far encirclement'- suggests prudence regarding increasing EU reliance on Russian gas, even with respect to those volumes conducted through secure routes. They may in fact necessitate a more active effort to ensure that Turkey's pipeline network is capable, not merely physically, but also politically, of advancing the collective EU interest in diversification of routes as well as suppliers. The regions in question containing significant potential third-party producers are surveyed below.

\section{The Caspian region}

In diametric contrast to the EU's situation vis-à-vis Russian gas, the EU has a more pressing need, not shared at all by Russia, for non-Russian FSU sources of gas to cross Turkey. During the Cold War, the Caspian Basin was largely Soviet territory, yet left relatively undeveloped by Moscow. Even now, most export routes cross Russia. Clearly, the EU's proclaimed policy of gas-supply diversification opposes the near monopsonistic (single buyer) and monopolistic (single seller) nature of Gazprom's control, via the Soviet-era Central Asia Centre (CAC) gas pipeline network, over extant gas exports from Kazakhstan, Turkmenistan and Uzbekistan. As expressed in the 1994 Energy Charter Treaty (ECT) and related Transit Protocol, the EU seeks to loosen Gazprom's and Transneft's respective chokeholds over CAC and the various oil pipelines that terminate at Russia's Black Sea and Baltic ports or cross directly into Europe (Olcott 2006, pp. 222-26; Roberts 2006, pp. 217-18; Belkin 2007, pp. 3, 11).

This chokehold may become even more constrictive if another planned Gazprom project to carry additional Turkmen and Kazakh gas northwards along the Caspian littoral via Russia to Europe reaches fruition (Rodova 2008a). The energy seller's market certainly firmed Moscow's opposition to ratifying the aforementioned European Energy Charter and Transit Protocol (Baev 2008). It also encouraged Moscow, acting through Transneft, which maintains a nearly one-quarter share in the project, to impose stringent conditions, including higher transit tariffs on expanding and using the only legally independent conduit with foreign corporate participation traversing Russian territory - the Caspian Pipeline Consortium (CPC) pipeline carrying affiliated Tengiz (Kazakhstan) oil to the Russian port of Novorossiisk (Socor 2007b). Russia reportedly conceded to CPC capacity expansions only on the condition that Kazakhstan participate in the aforementioned Transneft-led BurgasAlexandroupolis Pipeline (Ritchie 2008).

Earlier economic obstacles to the construction of non-Russian pipelines from the Caspian Basin were formidable. These stemmed both from the fact that pipelines, now controlled by Gazprom and Transneft, were already built and thus enjoyed advantages of 'incumbency' vis-à-vis proposed alternatives, even to the extent of locking many FSU states into Russia's economic orbit (Wohlforth 2004). Russia's cost advantage was reinforced by the evident economic infeasibility in the early post-Soviet era of building all of the 'multiple pipelines' forming the centrepiece of Clinton-era US government policy of fostering an East-West energy corridor (Jaffe \& Manning 1998-99, p. 118; Bahgat 2002, p. 323). Scepticism about the financial viability of non-Russian controlled Caspian pipeline infrastructure then undergoing construction lingered as late as the US-led invasion of Iraq in March 2003, widely anticipated to unleash a deluge of cheap 
hydrocarbon supplies (Andrianopoulos 2003, p. 80; Banerjee 2003; Williams \& Tekin 2008). However, by constricting that country's energy output, internal violence in postinvasion Iraq boosted hydrocarbon prices (Williams 2007) and improved the economics of Caspian-based projects. This underscores the fact that high prices support the entry of otherwise prohibitively expensive alternative sources and suppliers, lowering prices in the long term (Fusaro 2002, pp. 47-48; Maugeri 2006).

Consequently, Russia's former transportation stranglehold has been relaxed by newer projects that, despite over a decade of fitful progress, have finally come into operation. The BTC pipeline now transports oil, in volumes projected to reach 1.5 million barrels per day, from Azerbaijan's offshore territory via Turkey for (mostly) European customers. The parallel BTE pipeline [or South Caucasus Pipeline (SCP)] began in late 2007 to carry natural gas, in an amount that could eventually total $20 \mathrm{bcm}$ (including $6.6 \mathrm{bcm}$ for Turkey), offshore from Azerbaijan for shipment via Georgia to Turkey, from where it can be linked to various nodes of the European gas grid. According to a bilateral agreement, Turkey, while contractually prohibited from doing the same with Russian and Iranian gas, can deliver or 'on-sell' Azerbaijani energy received through these pipelines to European markets (Roberts 2004, pp. 1516). Greece and Turkey built a two-way pipeline interconnection between 2005 and 2007 able to carry up to $12 \mathrm{bcm}$ of natural gas (primarily Caspian) to Europe. Via extension, this line is expected to reach Italy and possibly even Albania, Macedonia and Bulgaria, all signatories to the Southeast European Energy Community Treaty (Winrow 2004, pp. 32-33). A distinct drawback of the lack of official coverage of Turkey in EU competition regulations relates to the fact that Turkey has insisted on the right to mark up the price of Azerbaijani gas going to Greece and Italy while forcing Greek and Italian purchasing firms, by way of intergovernmental agreement permitting Ankara to inspect the relevant contracts, to sell Turkey gas at the price paid to Azerbaijan (Socor 2008e). ${ }^{4}$

As European firms are prominent in the Caspian energy sector, they have a corollary interest in ensuring the most competitive terms for their oil and gas exports. British Petroleum (BP) leads the associated BTC and Azeri-Chirag-Guneshli (ACG) oilfield project consortia and shares leadership, with Norway's Statoil, of the complementary SCP and Shah Deniz gasfield projects. On the opposite littoral, Italy's Eni-Agip and British Gas control most of Kazakhstan's Karachaganak gas output and, with France's Total and Anglo-Dutch firm Shell (as well as ExxonMobil), own a combined three quarters of that country's Kashagan oil field, although state-led KazMunaiGaz unilaterally bolstered its share in 2007 to create an equal five-way division (Stern 2007). This oilfield could eventually supply — via tanker or undersea pipeline- the BTC pipeline, of which Total and Eni-Agip have a combined 10\% stake. Total has a one-tenth share of SCP as well, which could take Turkmen gas via a proposed Trans-Caspian line, estimated by Azeri officials to cost $\$ 5$ billion and to be capable of carrying $30 \mathrm{bcm}$ (Socor 2006b).

Relative to the decisiveness with which Europe's own private sector actors have aimed to tap gas supplies from the FSU Caspian littoral states, EU member

\footnotetext{
4‘Turkey, Greece Open Gas Link', Platt's International Gas Report, 3 December 2007, available at: http://global.factiva.com/aa/default.aspx, accessed 10 March 2008.
} 
governments have shown a more mixed attitude to Caspian energy. This ambivalence relates to members' heavier reliance on Russian gas, which has only exacerbated the pursuit by some of their companies, with official backing, of separate deals with Gazprom (Belkin 2007, pp. 9-13). Indeed, as the European Commission (2007a, pp. 18-19) admits, EU members have visibly struggled to 'speak with one voice' on common energy concerns. While Caspian gas would cover a small fraction of overall European imports, as the BTE line is to convey only about $10-15 \mathrm{bcm}$ per year of Azeri gas to Europe, a small volume compared to the EU's projected future annual consumption of $700 \mathrm{bcm}$ (Roberts 2004, pp. 2-3), it could hold gas prices down at the margins. ${ }^{5}$ Moreover, if additional increments of Caspian gas, from whichever country, were to find egress via Turkey to EU markets, this could strengthen Caspian states' economic independence and stability (Tekin \& Walterova 2007; United Nations Economic Commission for Europe 2006, p. 9). Nonetheless, Gazprom has acted more decisively to secure economic control over a wider array of Caspian natural gas supplies. Indeed, prolongation of the seller's market, which necessitates more rapid export of energy supplies from this landlocked region, and delays in building the Nabucco Project have opened the way for Gazprom to offer market prices for Turkmenistani and even Azerbaijani gas (Socor 2008e).

\section{The Middle East}

With world's largest combined hydrocarbon reserves, the Middle East and North Africa, which, as described below, are not immune to Russian influence, represent the least tractable areas for the EU to influence. Firstly, due to a longer period of extractive activity associated with Western colonial dominance and convenient access to seaborne transportation routes, this region already has ample production and export infrastructure. Secondly, regional countries have exerted output and pricing power via asset nationalisation, embargo and cartel action. As they did after the 19731974 Arab oil embargo (Skeet 1988, p. 118), and as they are now doing with Russia, European countries have largely adopted non-confrontational strategies, like dialogue, in seeking to lower or stabilise energy prices. Indeed, the European Commission (2001, p. 73) is attuned to the 'expectations of several producer countries regarding political developments in the Middle East'.

Like its European counterparts, Turkey has minimal influence over this region, although it has slightly more leverage on the gas issue, because of the continued prominence of Europe-orientated transit pipelines, than in the oil sector. For the past 30 years, punctuated by several periods of stoppage, Iraq has been a major exporter of crude oil via the Kirkuk-Yumurtalik pipeline that terminates in Ceyhan, Turkey. Post-occupation sabotage in Iraq had rendered the pipeline largely inoperable (Williams 2006) until late 2007. ${ }^{6}$ This may also have imparted a renewed impetus to a 1996 bilateral proposal to develop the annual capacity to pipe $10 \mathrm{bcm}$ of gas from

\footnotetext{
${ }^{5}$ Steven R. Mann, 'Remarks: Florence IEA Conference', 14 April 2003, available at: http:// www.iea.org/Textbase/work/2003/caspian/Mann.pdf, accessed 10 March 2008.

6،Iraq Oil Min: Iraq Currently Producing 2.5 Mln B/D', Dow Jones Commodities Service, 5 March 2008, available at: http://global.factiva.com/ha/default.aspx, accessed 10 March 2008.
} 
northern Iraq to Turkey (Roberts 2004, p. 7; Winrow 2004, p. 34). ${ }^{7}$ Russian firms, while expressing interest in investing in the Arab Persian Gulf, have been somewhat marginalised there, as exemplified by the case of Lukoil, which lost Saddam Husseinera contracts after the Iraqi occupation and has been excluded from more recent awards of service contracts to other major (Western) corporations (Kramer 2008a).

This is definitely not the case with Iran, which holds the world's third largest reserves and could constitute another major alternative source of European gas. Iranian gas has been estimated as capable of meeting more than $10 \%$ of the Union's medium term needs (European Commission 2005, p. 15). Given that most Iranian gas bound for Europe will flow through the Turkish network, bilateral Turkish-Iranian disputes cast an uncertain light on the viability of this transport route. Related to the underlying issue of Turkey's over-buying of imported gas supplies on a 'take-or-pay' basis, which also applies to Russia, Turkish authorities ceased Iranian imports in early 2003, just weeks after the $10 \mathrm{bcm}$-capacity Tabriz-Erzurum pipeline commenced operations, in an attempt to force changes in price, volumes and destination restrictions (Winrow 2004, pp. 29-30). Iran itself has stopped the flow of gas into this conduit, ostensibly to cover domestic shortages in the winter months over the past few years, a situation that was exacerbated in early 2008 by a decrease in the flow from Turkmenistan to Iran and that in turn caused a reduction in gas flows to the recently completed Turkey-Greece Interconnector. ${ }^{8}$

Russia also has multiple contacts with Iran in connection with energy issues. Moscow has used its permanent seat on the United Nations Security Council (UNSC) to block comprehensive multilateral sanctions extending to Iran's energy sector, not least because it seeks to have a role in developing civilian nuclear power at Iran's Bushehr site. Gazprom has also signed memoranda of understanding on investing in Iran's oil and gas fields, notably the vast South Pars formation (Eqbeli \& Shiryaevskaya 2008; Socor 2008c), thus filling the breach left by departing European and Asian private-sector firms. The implications of these plans for Nabucco are not necessarily negative in the short term. Given Russia's tentative support, together with major gas producers Algeria and Iran, for turning the Gas Exporting Countries Forum (GECF) into a more active 'gas-OPEC', they seem more strongly motivated by Gazprom's interest in augmenting its presence in the future LNG market (Shchedrov 2008). ${ }^{9}$

However, Gazprom has also been positioning itself along various segments of the Nabucco Project, either to undermine the project or to convert it into a conduit for gas supplies that originate in Russia, that are controlled by itself, or are produced by itself in extra-regional areas. Nabucco, expected to become operable in 2009, is to convey

\footnotetext{
${ }^{7}$ Turkey and Iraq Agree on Trade and Energy', Turkish Daily News, 9 August 2007, available at: http://www.turkishdailynews.com.tr/article.php?enewsid=80469, accessed 9 August 2007.

${ }^{8}$ Iran Cuts Gas Supply to Turkey', Platts, 12 December 2006, available at: http://www.platts.com/ Natural\%20Gas/News/8781901.xml, accessed 16 December 2006; and 'Factbox-Turkmenistan's Natural Gas Projects', Reuters, 7 February 2008, available at: http://global.factiva.com/ha/ default.aspx, accessed 10 March 2008.

9'Oil and Gas: Iran', Economist Intelligence Unit-Business Middle East, 1 March 2008, available at: http://global.factiva.com/ha/default.aspx, accessed 10 March 2008; 'Russia to Present Draft Charter of "Gas OPEC" on April 28', Platts, 21 April 2008, available at: http://www.platts.com/Natural\%20Gas/ News/8680370.xml, accessed 6 May 2008.
} 
assorted Caspian and Middle Eastern sources of natural gas, amounting to per annum volumes of up to $30 \mathrm{bcm}$, across Turkey to Europe, where Bulgaria, Romania, Hungary, Austria (Baumgarten is the intended terminus) and possibly France, will transport or consume a share of the piped gas. However, potentially contradicting the pipeline's purpose of diversifying Europe's gas suppliers, Hungary's MOL energy firm, one of six Nabucco consortium partners, agreed to undertake the rival South Stream project with Gazprom, and OMV, Austria's national energy company, consented to transform its Baumgarten gas storage and distribution hub into a joint venture with Gazprom (Socor 2008a). In addition, the project has also been affected by Turkey's opposition to the inclusion of Gas de France, whose home country has staunchly opposed Turkey's EU accession, as a seventh member company of the pipeline consortium (Özerkan 2008).

\section{Africa}

EU members do not enjoy immunity from attempts by its primary suppliers, including Russia, to influence the future potential nature and volume of African energy supplies to Europe. Egypt, a new LNG exporter, may also wish to use Turkey (after Jordan and Syria in succession) to pipe its gas to Europe. Accordingly, Egypt, Jordan, Syria, where Gazprom's construction subsidiary Stroitransgaz has built the Syrian leg, and Turkey agreed to extend a proposed Arab Gas Pipeline (AGP) project to Turkish territory, where additional connections could link it to Nabucco (Winrow 2004, pp. 34-35). ${ }^{10}$ Other than seeking to invest in Iran and participating in the AGP project, Gazprom has leveraged Soviet-era alliances with relevant regimes to enter various African energy sectors. In Libya, which exports gas via pipeline to Italy, which is involved in the proposed bi-directional Turkey-Greece-Italy Interconnector, Gazprom has acquired assets from a subsidiary German BASF firm that is party to a number of joint projects elsewhere, including Nord Stream (Socor 2006c). ${ }^{11}$ In 2008, in returning for agreeing to co-organise the marketing of additional Libyan gas supplies to Europe, Gazprom, replicating its strategy vis-à-vis Caspian FSU states, offered to purchase the entire volume of Libya's export-bound oil, gas and LNG supplies (Socor 2008c).

Compared to Libya, which supplied less than $4 \%$ of the European market in 2007, Algeria is much more salient in this regard. It provided $48 \mathrm{bcm}$ (just under two thirds of which came in the form of piped supplies to Italy and Spain), or 16\%, of Europe's total 2007 gas imports (derived from British Petroleum 2008). In 2006, Gazprom agreed with Sonatrach, Algeria's state energy firm, to produce gas and jointly market it to Europe in return for permitting the latter entity to join an LNG development in Russia (Socor 2007a). Gazprom has even begun exploring the possibility of producing Nigerian gas and delivering some of it via a proposed \$10-billion trans-Saharan pipeline to Algeria and from there to Europe (Gray 2008). These efforts correlate with Russian and Algerian interests in coordinating official positions in the aforementioned

\footnotetext{
${ }^{10}$ See also 'Egypt-Export Pipeline Project', APS Review Gas Market Trends, available at: http:// global.factiva.com/ha/default.aspx, accessed 10 March 2008.

${ }^{11}$ See also 'Libya Signs Oil Deal with Gazprom on Oil and Gas Production', RIA Novosti, available at: http://global.factiva.com/ha/default.aspx, accessed 10 March 2008.
} 
15-member-state GECF, a collaboration that could impact two fifths of Europe's market. Yet, this inchoate gas market cartelisation is presently hobbled by competition among pipeline-based suppliers (Chazan 2007) and thus seems targeted, for Gazprom, to ensuring its own security in future globalised LNG markets.

\section{Further EU interest in Turkish energy transport}

Underlying the claim that Turkey could aid EU energy security is the assumption that Turkish territory is a relatively cost effective means of conveying energy resources from East to West (Tekin \& Walterova 2007). As mentioned earlier, while Turkey is not a globally essential oil corridor for the EU, its hosting of the $\$ 3.2$ billion BTC crude oil pipeline may help not only to hold oil prices down at the margin, but also to allow Caspian crude in particular to compete with Russian and OPEC oil in Europe. Additional factors favouring landward Turkish oil transit is the fact that transporting Caspian oil (which is already being done in the limited form of tanker-borne 'swaps') by trans-Iranian pipelines to the Gulf, where countries can already load own crude supplies produced in that region, and then by tanker, is less economically viable than exporting it via Turkey to the Mediterranean. Moreover, Azerbaijan and Kazakhstan crude blends are more conducive than many of the typically heavier and more sour grades of the Persian Gulf to European refineries regulated by stricter environmental directives. ${ }^{12}$

In terms of gas, Central Asia, the Caspian and Iran are believed to hold enough gas to supply Europe through Turkey at reasonable costs. Consequently, developing conduits to ship this gas to Europe via Turkey could restrain the overall price that Gazprom can demand for its supplies (Gow 2008; Roberts 2004, pp. 17-18). ${ }^{13}$ The BTE or SCP line, the capacity of which British Petroleum initially set at 7-8 bcm, but later thought capable of being expanded to accommodate $20 \mathrm{bcm}$, suggesting that much of the gas would be shipped onwards to Europe, was projected in early 2004 to cost almost $\$ 1$ billion by the time of its expected completion (Roberts 2004, p. 6). Indeed, the SCP project played a key role in bolstering the viability of the BTC pipeline. Other than the overlapping memberships of the ACG-BTC and Shah DenizBTE consortia and economies of scale associated with building two pipelines along the same right-of-way, the Shah Deniz field's estimated 500 million barrels of oil condensate and additional possible crude reserves provided a potentially valuable increment to the quantity and quality of oil that could be shipped through the BTC line (Cutler 2000; Roberts 2004, p. 6).

Requiring upgrades and augmentations of its territorial pipeline infrastructure, Turkey needs more infusions of outside capital. As suggested above, Gazprom has its own reasons for preferring to serve as a possible candidate donor. Partially to avert any adverse consequences entailed in this scenario, the European Investment Bank

\footnotetext{
${ }^{12}$ Adams (2004). The EU, as expressed in the EC's 2003 Directive for the Promotion of Biofuels, is endeavouring to comply with the 1997 Kyoto Protocol and other EC directives pertaining to fuel quality standards and energy taxation (Pahl 2004, pp. 83-91).

${ }^{13}$ See also Steven R. Mann, 'Remarks: Florence IEA Conference', 14 April 2003, pp. 7-8, available at: http://www.iea.org/Textbase/work/2003/caspian/Mann.pdf, accessed 10 March 2008.
} 
(EIB) and European Bank for Reconstruction and Development (EBRD) have agreed to fund $70 \%$ of the estimated $\$ 5-6$ billion cost of the Nabucco pipeline (Socor 2006b), estimated by US officials to be capable of providing over $40 \mathrm{bcm}$ of gas (under the most optimistic eventual supply conditions) for as low as one fifth the cost of South Stream (Gow 2008). This could undergird development of a longer trans-Caspian energy corridor and pave the way for a transparent legal framework to promote investment in international energy projects.

\section{European energy security and the Turkish accession process}

While many have underscored the decisiveness of the moral and ethical logic behind the recent EU enlargement to Eastern Europe, others have emphasised the dominant role of geo-strategic reasons (Moravcsik \& Vachudova 2003; Sjursen 2002). For the latter, forward movement of the Turkish process finds its strongest explanation in the rational calculations of the EU (Önis 2000; Tekin 2005). Supporters of the Turkish membership have explicitly cited Turkey's advantages on energy security issues in EU Council internal debates. Some initially Turkey-sceptic leaders were seemingly convinced by this line of argument. Carl Bildt and Massimo D'Alema, foreign ministers of Sweden and Italy, respectively, wrote in a joint article that '... Turkey is a key actor in the realm of energy security. Given the uncertain state of energy markets, and the stakes involved, it is our shared interest to incorporate Turkey in a functioning integrated system' (Bildt \& D'Alema 2007).

Yet, EU official positions remain disparate on the issue. On the one hand, Olli Rehn, the Commissioner for Enlargement, has recently stated that

the EU and Turkey share essential strategic interests in security, economy and dialogue of civilizations. That is one of the reasons why the EU decided to open negotiations for membership with Turkey ... [Energy strategy] is an area where both the EU and Turkey can gain from deeper cooperation. ${ }^{14}$

On the other hand, the EU seems to hedge in line with the uncertainties surrounding the eventual fate of the accession talks, as manifested in the statements of Energy Commissioner Andris Piebalgs. He depicts the EU-Turkish energy cooperation as offering 'mutual benefits for both sides' and expresses determination 'to work together with Turkey to realize these mutual benefits'. He goes even further to state that

this is a process that ... has nothing to do with the EU accession - the one does not prejudge the other or vice versa ... they both stem from the understanding that further cooperation is needed between EU and Turkey in a number of fields. ${ }^{15}$

\footnotetext{
${ }^{14}$ Joint Press Release, 'Turkey and the EU: Together for a European Energy Policy'-High Level Conference in Istanbul, 5 June 2007, p. 1, available at: http://ec.europa.eu/enlargement/pdf/ european_energy_policy/joint_pressrelease_en.pdf, accessed 11 November 2008.

${ }^{15}$ Energy Commissioner Andris Piebalgs, 'EU and Turkey: Together for a European Energy Policy', speech delivered at the conference 'Turkey and the EU', Istanbul, 5 June 2007, pp. 4-5, available at: http://europa.eu/rapid/pressReleasesAction.do?reference=SPEECH/07/368\&format=HTML\&aged= $0 \&$ language $=\mathrm{EN} \&$ guiLanguage $=\mathrm{en}$, accessed 11 November 2008.
} 
EU official documents naturally use a guarded language in linking energy security issues to the Turkish accession process while emphasising the importance of Turkey in meeting EU energy policy objectives. The last Partnership Document for Turkey suggests completing the alignment of national legislation with the acquis as well as promoting the implementation in Turkey of 'projects of common interest' in the European Community Trans-European Networks-Energy Guidelines (The European Council 2008, Annex). The 2004 Progress Report on Turkey was the first one to discuss details of energy security issues. It concluded that 'Turkey will play a pivotal role in diversifying resources and routes for oil and gas transit from neighbouring countries to the EU' (European Commission 2004, p. 116). The most recent Progress Reports (2006 and 2007) focus on the Trans-European Networks (TENs). They repeat that 'The Nabucco natural gas pipeline project from the Caspian and Central Asian region to Europe via Turkey is among the priority projects of the EU, and Turkey should pursue efforts to support this project' (European Commission 2006b, p. 49, 2007b, p. 55).

The Screening Reports on the energy and TENs acquis chapters provide details of the developments within, and future expectations from, Turkey on energy security. The trans-European energy guidelines of 2006 identify priority projects and projects of common interest (European Commission 2006b). Building upon these guidelines, the screening report on Trans-European networks points out that

TEN-[Energy] respond to the growing importance for securing and diversifying the Community's energy supplies, incorporating the energy networks of the Member States and candidate countries, and ensuring the coordinated operation of the energy networks in the Community and in neighbouring countries. (European Commission 2007b, p. 2)

The Turkish side has expressed that it can accept the acquis regarding trans-European networks of energy by the time of accession (p. 2). The report asserts that Turkey, 'located in the vicinity of world's greatest energy reserves', is a 'natural connector' between the producer countries and the European energy markets (p. 4). The ongoing gas pipeline projects, connecting Turkey-Greece-Italy and Turkey-Austria (Nabucco), are both considered as 'TEN-E priority projects'. Turkey also suggests that other projects, such as Arab Gas Pipeline-Turkey interconnector, as well as the BakuTbilisi-Erzurum, Iraq-Turkey, and Trans-Caspian pipelines, should be considered as EU priority projects as they can link up to Mediterranean networks (p. 5). The report assesses that 'overall, Turkey has reached a satisfactory level of preparedness regarding the strategic development of the ... energy networks in accordance with the design and objectives of the ... TEN-E' (p. 5).

Compared to the guarded language of the EU official documents, less formal documents are slightly more forthcoming in linking Turkey's role in European energy security with its accession process. For instance, in June 2007, a conference in Istanbul dealt with the common challenges and opportunities for the EU and Turkey in the energy field. The joint statement of Turkish and Commission leaders emphasised the importance of strategic cooperation and the exploitation of Turkey's geographic location in providing energy security for Europe. More precisely, these leaders indicated that 'as Turkey is moving forward in the accession process, coherent policies will need to be implemented with a view to ensuring secure access to the 
energy resources of the region and their safe arrival to the markets. ${ }^{16}$ In sum, the EU as an institution recognises Turkey's potential value as a secure and independent (of Russia) route for EU energy supplies, which may in turn assist Turkey's accession process.

\section{Conclusion}

The preceding discussion makes amply clear that the EU cannot easily diversify its energy suppliers. Currently, the EU largely depends on three main supply regions, two of which, the FSU (Russian and Russian-controlled exports from the Central Asian states of the Caspian Basin) and North Africa, are fully external to the EEA. Key to diversification, especially in the area of gas, seems to be increasing imports from a wider range of suppliers in the Middle East (including Egypt, Iran and Iraq) as well as developing an independent means of accessing energy supplies from Kazakhstan, Turkmenistan and Uzbekistan, the aforementioned Central Asian states. This would enlarge the volume of Caspian supplies beyond those from Azerbaijan that currently reach Europe without crossing Russian territory.

In regards to the latter challenge, a Turkish energy corridor seems to offer one of the only feasible modes of connecting a greater diversity of suppliers to Europe via secure and independent routes. However, as shown above, treating Turkey's capacity and willingness to serve as a transit country, primarily in terms of gas, as a matter to be addressed within existing frameworks of cooperation may not be enough to ensure Europe's energy security. The proposed energy networks, associated with such mammoth infrastructural undertakings as the Turkey-Greece-Italy Interconnector or the Nabucco Pipeline, which have been prioritised by the European Commission, involve the higher standardisation and integration of regulatory environments characteristic of political union. Thus, more serious efforts by the EU to diversify supply and secure those diverse supplies may come to require less ambivalence on the question of Turkey's accession.

Harvard University and Bilkent University

\section{References}

Adams, T. (2004) 'Caspian Hydrocarbons, the Politicisation of Regional Pipelines, and the Destabilisation of the Caucasus', available at: http://poli.vub.ac.be/publi/crs/eng/Vol5/adams. htm, accessed 10 March 2008.

Andrianopoulos, A. (2003) 'The Economics and Politics of Caspian Oil', Southeast Europe and Black Sea Studies, 3, 3.

Baev, P.K. (2006) 'Europe Calls Gazprom's Bluff and Ponders its Threat', Eurasia Daily Monitor, 24 April, available at: http://www.jamestown.org/edm/article.php?article_id=2371012, accessed 10 March 2008.

Baev, P.K. (2008) 'Medvedev's Sweet-Talking Narrows the Rift in EU-Russian Relations', Eurasia Daily Monitor, 30 June, available at: http://www.jamestown.org/edm/article.php?article_id= 2373186, accessed 30 July 2008.

\footnotetext{
${ }^{16}$ Joint Press Release, 'Turkey and the EU: Together for a European Energy Policy'-High Level Conference in Istanbul, 5 June 2007, item 11, available at: http://ec.europa.eu/enlargement/pdf/ european_energy_policy/conference_statement_final_en.pdf, accessed 11 November 2008.
} 
Bahgat, G. (2002) 'Pipeline Diplomacy: The Geopolitics of the Caspian Region', International Studies Perspectives, 3,3 .

Banerjee, N. (2003) 'With the War Largely Over, OPEC Fears a Price Drop', New York Times, 21 April.

Barnes, J., Hayes, M.H., Jaffe, A.M. \& Victor, D.G. (2006) 'Introduction and Context', in Victor D.G., Jaffe, A.M. \& Hayes, M.H. (eds) (2006).

Barysch, K. (2007) 'What Europeans Think about Turkey and Why', Center for European Reform Briefing Note, August, available at: http://www.cer.org.uk/pdf/briefing_kb_turkey_24aug07.pdf, accessed 11 November 2008.

Belkin, P. (2007) 'The European Union's Energy Security Challenges', CRS Report for Congress, 7 May (Washington, DC, Congressional Research Service).

Bildt, C. \& D'Alema, M. (2007) 'It's Time for a Fresh Effort', International Herald Tribune, 31 August.

British Petroleum (2008) BP Statistical Review of World Energy June 2008, available at: http:// www.bp.com/liveassets/bp_internet/globalbp/globalbp_uk_english/reports_and_publications/stat istical_energy_review_2008/STAGING/local_assets/downloads/pdf/statistical_review_of_world_ energy_full_report_2008.pdf, accessed 31 July 2008.

Brunwasser, M. \& Dempsey, J. (2008) 'Pipeline Cements Russia's Hold on Europe's Gas Supply', New York Times, 19 January.

Buzan, B., Waever, O. \& de Wilde, J. (1998) Security: A New Framework for Analysis (Boulder \& London, Lynne Rienner).

Chazan, G. (2007) 'Algeria-Russia Split on Gas Helps Europe', Wall Street Journal, 10 December.

Chivers, C.J. (2006) 'For Putin and the Kremlin, a Not So Happy New Year', New York Times, 3 January.

Cutler, R.C. (2000) 'Just When You Thought Baku-Ceyhan was Dead and Buried: Part 7, Conclusion', Alexander's Gas \& Oil Connections, 26 May, available at: http://www.gasandoil.com/ goc/news/ntc02156.htm, accessed 10 March 2008.

Eqbeli, A. \& Shiryaevskaya, A. (2008) 'Iran, Gazprom Ink MOU, to Set Up Joint Energy Company', Platts, 13 July, available at: http://www.platts.com/OIL/News/9088054.xml, accessed 15 July 2008.

European Commission (2001) 'Green Paper: Towards a European Strategy for the Security of Energy Supply', available at: http://ec.europa.eu/energy/green-paper-energy-supply/doc/green_paper_ energy_supply_en.pdf, accessed 11 November 2008.

European Commission (2002) 'Energy: Let Us Overcome Our Dependence', available at: http:// ec.europa.eu/energy/green-paper-energy-supply/doc/green_paper_energy_supply_short_en.pdf, accessed 11 November 2008.

European Commission (2004) '2004 Regular Report on Turkey's Progress towards Accession', available at: http://ec.europa.eu/enlargement/archives/pdf/key_documents/2004/rr_tr_2004_en. pdf, accessed 11 November 2008.

European Commission (2005) 'Report on the Green Paper on Energy: Four Years of European Initiatives', available at: http://www.jet.efda.org/documents/ad-hoc/2005-green-paper-reporten.pdf, accessed 11 November 2008.

European Commission (2006a) 'Green Paper: A European Strategy for Sustainable, Competitive and Secure Energy', available at: http://ec.europa.eu/energy/green-paper-energy/doc/2006_03_ 08_gp_document_en.pdf, accessed 11 November 2008.

European Commission (2006b) 'Turkey 2006 Progress Report', available at: http://ec.europa.eu/ enlargement/pdf/key_documents/2006/nov/tr_sec_1390_en.pdf, accessed 11 November 2008.

European Commission (2007a) 'Communication from the Commission to the European Council and the European Parliament: An Energy Policy for Europe', available at: http://eur-lex.europa.eu/ LexUriServ/LexUriServ.do?uri=COM:2007:0001:FIN:EN:PDF, accessed 11 November 2008.

European Commission (2007b) 'Turkey 2007 Progress Report', available at: http://ec.europa.eu/ enlargement/pdf/key_documents/2007/nov/turkey_progress_reports_en.pdf, accessed 11 November 2008 .

European Council (2004) 'Council Directive 2004/67/EC of 26 April 2004 Concerning Measures to Safeguard Security of Natural Gas Supply', Official Journal of the European Union, 29 April 2004, available at: http://eur-lex.europa.eu/LexUriServ/LexUriServ.do?uri=OJ:L:2004:127:0092:0096: EN:PDF, accessed 11 November 2008.

European Council (2008) '2008/157/EC: Council Decision of 18 February on the principles, priorities and conditions contained in the Accession Partnership with the Republic of Turkey and repealing Decision 2006/35/EC', Official Journal L 051, 26 February, pp. 4-18, available at: http://eurlex.europa.eu/LexUriServ/LexUriServ.do?uri=OJ:L:2008:051:0004:01:EN:HTML， accessed 19 December 2008. 
Fusaro, P.C. (2002) 'The Future Importance of Oil: Geopolitical Lynchpin or Common Commodity?', in Bloomfield, L.P. Jr (ed.) (2002) Global Markets and National Interests: The New Geopolitics of Energy, Capital, and Information (Washington, DC, Center for International and Strategic Studies).

Gow, D. (2008) 'US Tells Europe to Stop Dithering Over Pipeline', The Guardian, 23 February.

Gray, T. (2008) 'Gazprom Seeks to Break Down Barriers in Nigeria', Lloyd's List, 31 January.

Jaffe, A.M. \& Manning, R.A. (1998-99) 'The Myth of the Caspian "Great Game": The Real Geopolitics of Energy', Survival, 40, 4.

Johnson, D. (2005) 'EU-Russian Energy Links: A Marriage of Convenience?', Government and Opposition, 40, 2.

Kramer, A.E. (2005) 'Russia Plans to Use Turkey as a Gas Hub', New York Times, 18 November.

Kramer, A.E. (2008a) 'US Advised Iraqi Ministry on Oil Deals', New York Times, 30 June.

Kramer, A.E. (2008b) 'Denied Visa, Chief of BP Joint Venture is Forced to Leave Russia', New York Times, 25 July.

Larsson, R.L. (2007) Nord Stream, Sweden and Baltic Sea Security, Base Data Report, March 2007 (Stockholm, FOI-Swedish Defence Research Agency).

Maugeri, L. (2006) 'Two Cheers for Expensive Oil', Foreign Affairs, 85, 2.

Moravcsik, A. \& Vachudova, M.A. (2003) 'National Interests, State Power, and EU Enlargement', East European Politics and Societies, 17, 1.

Myers, S.L. (2007) 'Belarus Signals Resolution in Oil Dispute', New York Times, 11 January.

Olcott, M.B. (2006) 'International Gas Trade in Central Asia: Turkmenistan, Iran, Russia, and Afghanistan', in Victor, D. G., Jaffe, A.M. \& Hayes, M.H. (eds) (2006).

Önis, Z. (2000) 'Luxembourg, Helsinki and Beyond: Towards an Interpretation of Recent Turkey-EU Relations', Government and Opposition, 35, 4.

Özerkan, F. (2008) 'Turkey says Nabucco Political Project', Turkish Daily News, 15 February.

Pahl, G. (2004) Biodiesel: Growing a New Energy Economy (White River Junction, Chelsea Green Publishing Company).

Rettman, A. (2006) 'EU Caucasus Trip Opens New Policy Horizon', EU Observer, 15 February, available at: http://www.securitydefenceagenda.org/news_detail.asp?ID=677, accessed 12 February 2007.

Ritchie, M. (2008) 'Russia: The Putin Doctrine', Energy Compass, 4 January, available at: http:// global.factiva.com/ha/default.aspx, accessed 10 March 2008.

Roberts, J. (2004) The Turkish Gate: Energy Transit and Security Issues (Brussels, Centre for European Policy Studies).

Roberts, J.M. (2006) 'The Black Sea and European Energy Security', Southeast Europe and Black Sea Studies, 6, 2.

Rodova, N. (2008a) 'Gazprom Willing to Cooperate on Caspian Gas Routes', Platts, 4 July, available at: http://www.platts.com/Natural\%20Gas/News/8856234.xml, accessed 28 July 2008.

Rodova, N. (2008b) 'Russia's Rosneft Suggests Joint Sakhalin Development with Gazprom', Platts, 22 July, available at: http://www.platts.com/Natural\%20Gas/News/8896557.xml, accessed 28 July 2008.

Romero, S. (2006) 'A Dispute Underscores the New Power of Gas', New York Times, 3 January.

Shan, W. (2007) "From "North-South Divide" to "Private-Public Debate": Revival of the Calvo Doctrine and the Changing Landscape of International Investment Law', Northwestern Journal of International Law \& Business, 27, 591.

Shchedrov, O. (2008) 'Russia, Algeria Talk Energy, Mum on Gas OPEC', Reuters, 19 February.

Shiryaevskaya, A. (2008) 'Russia Calls for Fast Work on Oil, Gas Lines to Southern Europe', Platts, 29 July, available at: http:/www.platts.com/Oil/News/9156654.xml, accessed 30 July 2008.

Shiryaevskaya, A. \& Kumagai, T. (2008) 'Japanese Companies Eye New Russian LNG Plants: METI', Platts, 24 July, available at: http://www.platts.com/Natural\%20Gas/News/8903624.xml, accessed 30 July 2008.

Simmons, M.R. (2005) Twilight in the Desert: The Coming Saudi Oil Shock and the World Economy (Hoboken, NJ, John Wiley \& Sons).

Sjursen, H. (2002) 'Why Expand? The Question of Legitimacy and Justification in the EU's Enlargement Policy', Journal of Common Market Studies, 40, 3.

Skeet, I. (1988) OPEC: Twenty-five Years of Prices and Politics (Cambridge, Cambridge University Press).

Socor, V. (2006a) 'Gazprom Broadens, Deepens Inroads Into European Union's Internal Markets, Transport Systems', Eurasia Daily Monitor, 21 March, available at: http://www.jamestown.org/ edm/article.php?article_id=2370893, accessed 10 March 2008. 
Socor, V. (2006b) 'Azerbaijan Spearheading Initiative on Trans-Caspian Gas Pipeline', Eurasia Daily Monitor, 30 March, available at: http://www.jamestown.org/edm/article.php?article_id=2370929, accessed 10 March 2008.

Socor, V. (2006c) 'Gazprom Picks Off One Large German Morsel, Poised for Another', Eurasia Daily Monitor, 3 May, available at: http://www.jamestown.org/edm/article.php?article_id=2371044, accessed 10 March 2008.

Socor, V. (2006d) 'Pipeline Project Can Diversify Europe's Gas Supplies', Eurasia Daily Monitor, 30 June, available at: http://www.jamestown.org/edm/article.php?article_id=2371236, accessed 10 March 2008

Socor, V. (2007a) 'Kremlin Energy Strategy Targets Western Energy Assets in Russia, Western Supply Sources in Third Countries', Eurasia Daily Monitor, 23 January, available at: http:// www.jamestown.org/edm/article.php?article id=2371827, accessed 10 March 2008 .

Socor, V. (2007b) 'Western Majors Sign Agreement on Intent on Trans-Caspian Oil Transport System', Eurasia Daily Monitor, 25 January, available at: http://www.jamestown.org/edm/ article.php?article_id=2371838, accessed 10 March 2008.

Socor, V. (2008a) 'Sourcing the Nabucco Pipeline to Prevail Against South Stream', Eurasia Daily Monitor, 8 February, available at: http://www.jamestown.org/edm/article.php?article_id= 2372789, accessed 10 March 2008.

Socor, V. (2008b) 'Austrian Government, OMV Joining Gazprom's South Stream Project, Undercut Nabucco', Eurasia Daily Monitor, 10 June, available at: http://www.jamestown.org/edm/ article.php?article_id=2373130, accessed 30 July 2008.

Socor, V. (2008c) 'Gazprom on a Shopping Spree for Gas', Eurasia Daily Monitor, 14 July, available at: http://www.jamestown.org/edm/article.php?article_id=2373223, accessed 30 July 2008.

Socor, V. (2008d) ‘Gazprom Hit by Gas Shortfall’, Eurasia Daily Monitor, 17 July, available at: http:// www.jamestown.org/edm/article.php?article id=2373236, accessed 30 July 2008.

Socor, V. (2008e) 'A Political Summit Might Resuscitate the Nabucco Project', Eurasia Daily Monitor, 21 July, available at: http://www.jamestown.org/edm/article.php?article_id=2373244, accessed 30 July 2008.

Stern, D.L. (2007) 'Kazakh Leader Suggests Way to End Oil Standoff', New York Times, 8 December.

Tekin, A. (2005) 'Future of Turkey-EU Relations: A Civilisational Approach', Futures, 37, 4.

Tekin, A. \& Walterova, I. (2007) 'Turkey's Geopolitical Role: The Energy Angle', Middle East Policy, 14,1 .

Torbakov, I. (2006a) 'Europe Rejects Gazprom's Ultimatum', Eurasia Daily Monitor, 21 April, available at: http://www.jamestown.org/edm/article.php?article_id=2371009, accessed 10 March 2008.

Torbakov, I. (2006b) 'Kremlin Tries to Convince Wary West That Strong Gazprom is Good for It', Eurasia Daily Monitor, 28 April, available at: http://www.jamestown.org/edm/article. php?article id=2371034, accessed 10 March 2008

United Nations Commission for Europe (2006) 'Report on Global Energy Security and the Caspian Sea Region: Country Profiles', available at: http://www.unece.org/ie/se/pdfs/comm15/ECE. ENERGY.2006.3.Add.1_e.pdf, accessed 10 March 2008.

United States Central Intelligence Agency (2008) World Factbook, available at: https://www.cia.gov/ library/publications/the-world-factbook/geos/rs.html, accessed 31 July 2008.

Victor, D.G., Jaffe, A.M. \& Hayes, M.H. (eds) (2006) Natural Gas and Geopolitics: From 1970 to 2040 (Cambridge, Cambridge University Press).

Victor, N.M. (2006) 'Russia's Gas Crunch: Looming Shortfall Poses a Tough Choice', Washington Post, 6 April.

Victor, N.M. \& Victor, D.G. (2006) 'Bypassing Ukraine: Exporting Russian Gas to Poland and Germany', in Victor, D.G., Jaffe, A.M. \& Hayes, M.H. (eds)

White, G. (2008) 'Gas-Supply Battle Escalates Between Russia and Ukraine', Wall Street Journal Europe, 5 March.

Williams, P.A. (2006) 'Projections for the Geopolitical Economy of Oil after War in Iraq', Futures, $38,9$.

Williams, P.A. (2007) 'Market Cycles, Power Politics and the Latest North-South Energy Trade Conflict', Third World Quarterly, 28, 1.

Williams, P.A. \& Tekin, A. (2008) 'The Iraq War, Turkey, and Renewed Caspian Energy Prospects', Middle East Journal, 62, 3.

Winrow, G.M. (2003) 'Pivotal State or Energy Supplicant?: Domestic Structure, External Actors, and Turkish Policy in the Caucasus', Middle East Journal, 57, 1.

Winrow, G.M. (2004) 'Turkey and the East-West Gas Transportation Corridor', Turkish Studies, 5, 2. 
Woehrel, S. (2007) 'Russian Energy Policy toward Neighboring Countries', CRS Report for Congress, 27 November (Washington, DC, Congressional Research Service).

Wohlforth, W.C. (2004) 'Revisiting Balance of Power Theory in Central Eurasia', in Paul, T.V., Wirtz, J.J. \& Fortmann, M. (eds) (2004) Balance of Power: Theory and Practice in the 21st Century (Stanford, Stanford University Press).

World Bank (2007) 'Russian Federation at a Glance', 28 September, available at: http:// devdata.worldbank.org/AAG/rus_aag.pdf, accessed 30 July 2008. 